\title{
Analisis Kemampuan Metakognitif Siswa dalam Menyelesaikan Soal ditinjau dari J enis Kelamin pada Materi Listrik Statis
}

\author{
Alvionica Hartin ${ }^{1}$, Tomo Djudin², Nurussaniah ${ }^{1}$ \\ ${ }^{1}$ Prodi Pendidikan Fisika, IKIP PGRI Pontianak, Pontianak 78166, Indonesia. \\ ${ }^{2}$ Prodi Pendidikan Fisika, Universitas Tanjungpura Pontianak, Pontianak 78124, Indonesia \\ e-mail: alvionicahartin26@gmail.com; tomo.djudin@yahoo.com; nurussaniah@gmail.com
}

\begin{abstract}
Abstrak
Penelitian ini bertujuan untuk mendeskripsikan profil kemampuan metakognitif siswa di dalam menyelesaikan soal pada materi listrik statis, mengetahui bagaimana kemampuan metakognitif siswa berdasarkan jenis kelamin. Metode yang digunkan adalah penelitian deskriptif dengan pendekatan kuantitatif. Bentuk penelitian adalah survei, instrumen adalah angket kemampuan metakognitif dan soal tes essai listrik statis. Sampel penelitian adalah siswa kelas XII MAN 1 Singkawang berjumlah 25 orang siswa laki-laki dan 30 orang siswa perempuan. Data dalam penelitian ini dianalisis menggunakan statisik deskriptif dan uji $t$ indenpendent sampel menggunakan SPSS. Berdasarkan hasil penelitian dapat disimpulkan bahwa, rata-rata kemampuan metakognitif pada aspek perencanaan sebesar $76,59 \%$, aspek monitoring sebesar $73,09 \%$ dan evaluasi sebesar $67,64 \%$. Terdapat perbedaan antara kemampuan metakognitif siswa laki-laki dan siswa perempuan dengan nilai ( thitung $=2,236>$ tabel $=2,005$ ).
\end{abstract}

Kata Kunci: Kemampuan metakognitif, dalam menyelesaikan soal, Listrik Statis.

\section{Analysis of Students' Metacognitive Ability in Solving Problems in terms of Gender On Static Electricity}

\begin{abstract}
This study aims to describe the profile of students 'metacognitive abilities in solving problems on static electricity material, knowing how students' metacognitive abilities are based on gender. The method used is descriptive research with a quantitative approach. The form of research is a survey, the instrument is a metacognitive ability questionnaire and static electricity essay test questions. The research sample was students of class XII MAN 1 Singkawang totaling 25 male students and 30 female students. Data in this study were analyzed using descriptive statistics and independent sample t test using SPSS. Based on the results of the study it can be concluded that, the average metacognitive ability in the planning aspect is $76.59 \%$, the monitoring aspect is $73.09 \%$ and the evaluation is $67.64 \%$. There is a difference between the metacognitive abilities of male and female students with grades (tcount $=2.236>$ table $=2.005$ ).
\end{abstract}

Keywords: Metacognitive ability, in solving problems, Static electricity.

How to Cite: H, Alvionica., D, Tomo., N, Nurussaniah. (2020). Analisis Kemampuan Metakognitif Siswa dalam Menyelesaikan Soal ditinjau dari Jenis Kelamin Pada Materi Listrik Statis. Jurnal Pendidikan Fisika dan Keilmuan (JPFK), 6(1), 39-46. doi: https://doi.org/10.25273/jpfk.v6i1.5472 


\section{PENDAHULUAN}

Kurikulum pendidikan yang diterapkan di Indonesia pada tahun ajaran 2018/2019 adalah kurikulum 2013. Dalam implementasinya kurikulum 2013 menetapkan kompetensi lulusan pendidikan dasar dan menengah salah satunya adalah kompetensi metakognitif untuk menciptakan lulusan pendidikan yang berkualitas. Kemendikbud (2016) menyebutkan tentang standar Kompetensi Lulusan Pendidikan Dasar dan Menengah yaitu, untuk kompetensi kemampuan lulusan adalah memiliki pengetahuan faktual, konseptual, prosedural dan metakognitif. Berdasarkan standar kompetensi lulusan tersebut, maka pencapaian kompetensi metakognitif menjadi salah satu tujuan dalam implementasi kurikulum 2013.

Metakognitif dinyatakan oleh Iskandar (2016) merupakan suatu istilah yang diperkenalkan oleh Flavell pada Tahun 1976, kegiatan metakognitif pada dasarnya merupakan kegiatan thinking about thingking (berpikir tentang berpikir), yaitu merupakan kegiatan mengontrol secara sadar tentang proses kognitifnya sendiri. Kegiatan metakognitif meliputi kegiatan berfikir untuk merencanakan, memonitoring, dan merefleksi bagaimana menyelesaikan suatu masalah.

Para ahli membagi metakognitif menjadi dua komponen yaitu pengetahuan metakognitif dan pengalaman metakognintif. Pengetahuan metakognitif adalah kesadaran seseorang tentang apa yang sesungguhnya. Aswadi et al. (2018) membagi pengetahuan metakognitif menjadi tiga bagian, yaitu; (1) pengetahuan strategis, (2) pengetahuan tentang tugas kognitif, termasuk pengetahuan kontekstual dan kondisional dan (3) pengetahuan tentang diri sendiri. Sedangkan pengalaman metakognitif adalah bagaimana seseorang mengatur aktivitas kognitifnya secara efektif. Pengalaman metakognitif berpengaruh terhadap prosesproses kognitif yang sedang berlangsung dalam situasi yang menurut pemikiran yang membutuhkan kesadaran. Proses mengontrol aktivitas kognitif tersebut terdiri dari perencanaan, monitoring dan evalusai.

Dalam sudut pandang lain, metakognitif didefinisikan sebagai keterampilan kompleks yang dibutuhkan siswa untuk menguasai suatu jangkauan keterampilan khusus, kemudian mengumpulakan kembali keterampilan-keterampilan ini ke dalam startegi belajar yang terhadap suatu masalah khusus atau konteks yang berbeda. Djudin (2017) mengemukakan keterampilan metakognitif termasuk mengambil kendali pembelajaran secara sadar, merencanakan dan memilih strategi, memantau kemajuan pembelajaran, menganalisis efektivitas starategi pembelajaran memperbaiki kesalahan, menganalisis efektifitas strategi pembelajaran, dan mengubah prilaku dan starategi belajar bila diperlukan.

Meskipun terdapat bermacam-macam pendapat tentang komponen metakognitif namun pada hakekatnya para pakar berpendapat bahwa komponen atau indikator metakognitif terdiri dari tiga elemen dalam menghadapi masalah, yaitu (1) menyusun startegi atau rencana tindakan; (2) Memonitoring tindakan; dan (3) Mengevaluasi tindakan.

Materi listrik statis merupakan salah satu materi dalam fisika yang diajarkan pada siswa jenjang Sekolah Madrasah Aliyah Negeri (MAN) khususnya pada kelas XII. Materi ini memerlukan pemahaman konsep yang mendalam pada penerapannya untuk dapat menyelesaikan soal-soal yang berhubungan dengan materi tersebut. Dalam penerapanya sebagian besar siswa mengalami kesulitan dalam memahami apa yang dimaksud dalam soal, yang berakibat pada tidak mampu mengubah soal kedalam bentuk matematika serta tidak dapat menulis data-data yang diketahui secara tepat. Seperti hasil penelitian Juwariyah (2018)

J urnal Pendidikan Fisika dan Keilmuan (J PFK), Vol. 6, No. 1, Maret 2020, 39-46. 
mendapatkankan kesalahan yang paling dominanan yang dilakukan siswa dalam menyelesaikan soal pada materi listrik statis di MAN 6 Jombang yaitu kesalahan konsep sebesar $51,18 \%$ yang menunjukan kategori kesalahan sedang dan dilanjutkan dengan kesalahan terjemahan sebesar $37,78 \%$ yang menunjukan kategori sedang. Dalam metakognitif hal ini menunjukan bahwa siswa belum dapat menentukan startegi yang digunakan dalam menyelesaikan soal dalam aspek perencanaan yang sangat diperlukan siswa dalam pemecahan masalah.

Berdasarkan hasil observasi kepada guru fisika dan siswa kelas XII IPA MAN 1 Singkawang diperoleh infromasi bahwa minimnya pengetahuan guru dan siswa mengenain kemampuan metakognitif. Sehingga di sekolah ini guru dan siswa masih belum terbiasa untuk mengembangkan kemampuan metakognitifnya pada tiap indikator kemampuan metakognitif. Hal ini terlihat ketika beberapa orang siswa ditanya bagaimana mereka menyelesaikan soal fisika, beberapa siswa menjawab mengalami kesulitan untuk menetukan persamaan dalam menyelesaikan soal fisika. kemudian siswa lain menjawab sering melakukan kesalahan dalam ketelitian dan perhitungan. Kesulitan lain yang dialami siswa yaitu ketika menemukan bentuk soal yang berbeda dengan soal yang pernah diajarkan oleh guru. Keadaan ini menunjukan kemampuan siswa dalam perencanaan, monitoring dan evaluasi yang merupkan bagian dari kemampuan metakognitif masih belum optimal. Kemudian ketika guru tidak mengetahui pentingkan kemampuan metakognitif dalam pembelajaran menyebabkan pembelajaran yang berlangsung hanya berorientasi pada hasil saja dan kurang memberdayakan kemampuan berpikir siswa, sehingga siswa hanya mempelajari fisika pada aspek kognitif yang rendah.

Lebih lanjut hasil penelitian Muhali (2013) yang dilakukan dibeberapa sekolah untuk mengetahui gambaran keadaan kemampuan metakognitif siswa, menunjukan bahwa persentase kemampuan metakognitif siswa secara keseluruhan pada setiap indikator menunjukan kemampuan metakognitif mereka yang kurang baik (dengan pencapaian persentase tiap indikator $<60 \%$ ). Hasil penelitian ini juga menujukan bahwa masih banyak sekolah dan pendidik yang belum menyadari akan pentingnya kemampuan metakognitif untuk keberahasil proses pembelajaran.

Selain kemampuan metakognitif hal lain yang dapat berpengaruh terhadap proses pembelajaran siswa adalah gender atau jenis kelamin sebagai faktor internal pada aspek psikologi. Seperti yang kita ketahui bahwa siswa memiliki kemampuan belajar yang berbeda-beda antara siswa laki-laki dan siswa perempuan. Selain itu, dalam belajar juga diketahui adanya perbedaan hasil belajar siswa laki-laki dan siswa perempuan, khusunya dalam pembelajaran sains. Pernyataan ini sesuai dengan hasil penelitian (Dilla et al., 2018) mendapatkan perbedaan hasil belajar matematika siswa laki-laki dan siswa perempuan dimana nilai rata-rata siswa perempuan lebih tinggi dibanding nilai rata-rata siswa laki-laki. Dengan demikian memang ada perbedaan jenis kelamin di dalam kemampuan penalaran matematik dan sains.

Berdasarkan uraian di atas maka penelitian ini dilakukan untuk menganalisis kemampuan metakogitif siswa dalam menyelesaikan soal pada meteri listrik statis ditinjau dari jenis kelamin. Bagian kemampuan metakognitif yang akan dianalisi dalam peneltitian ini adalah pengetahuan strategi metakognitif yang mencakup perencanaan, monitoring dan evaluasi. Penelitian ini bertujuan untuk melihat profil atau gambaran keadaan kemampuan metakognitif siswa dalam menyelesaikan soal listrik statis ditinjau dari jenis kelamin yang akan dilakukan di MAN 1 Singkawang kelas XII Semester 1 Tahun Ajaran 2019/2020. Kemudian selajutnya 
diharapkan kepada semua guru atau pendidik dapat mempelajari dan menindak lanjuti kemampuan metakognitif siswa yang besar pengaruhnya pada kemampuan proses berpikir dan hasil belajar siswa.

\section{METODE PENELITIAN}

Penelitian ini dilakukan pada tanggal tanggal 31 Juli s/d 1 Agustus 2019 di MAN 1 Singkawang. Metode yang digunakan dalam penelitian ini adalah penelitian deskriptif dengan pendekatan kuantitatif, bentuk penelitian adalah survey. Variabel dalam penelitian ini adalah kemampuan metakognitif siswa dalam menyelesaikan soal listrik statis.

Populasi dalam penelitian ini adalah Seluruh siswa kelas XII MAN 1 Singkawang. Sampel dalam peneltian ini ditentukan dengan cara Proportionate Stratified Random Sampling menggunakan tabel penentuan jumlah sampel dari populasi dengan taraf kesalahan 5\% menurut Sugiyono (2017) dengan jumlah 25 orang siswa laki-laki dan 30 orang siswa perempuan.

Teknik pengumpulan data yang digunkan dalam penelitian ini adalah teknik komunikasi tidak langsung dan teknik pengukuran. Instrumen yang digunakan berupa angket kemampuan metakognitif sebanyak 24 butir dan soal listrik statis sebanyak 5 soal.

Prosedur penelitian yang digunakan terbagi dalam tiga tahap yaitu:

\section{Tahap Persiapan}

Langkah-langkah yang dilakukan pada tahap persiapan antara lain : (1) Observasi kesekolah dilakukan di MAN 1 Singkawang; (2) Menyiapkan Instrumen penelitian berupa angket dan soal essai; (3) Melakasanankan validitas instrumen penelitian; (4) Mengajukan surat izin permohonan untuk meneliti kepada kepala sekolah.

\section{Tahap Pelaksanaan}

Langkah-langkah yang dilakukan pada tahap pelaksanaan antara lain: (1) Membagikan instrumen angket kemampuan metakognitif kepada siswa (2) Memberikan soal tes listrik statis kepada siswa

\section{Tahap Akhir}

Langkah-langkah yang dilakukan pada tahap akhir antara lain: (1) Mengolah data hasil penelitian; (2) Mendeskripsikan hasil pengolahan data dan meyimpulkan sebagai jawaban dari masalah dalam penelitian (3) Menyusun laporan penelitian

\section{HASIL DAN PEMBAHASAN}

Hasil penelitian ini meliputi data profil kemampuan metakognitif siswa dalam menyelesaikan soal yang akan dikelompokan dalam kemampuan tinggi, sedang dan rendah, kemampuan metakognitif berdasarkan jenis kelamin dalam menyelesaikan soal. Data-data hasil penelitian ini dianalisis berdasarkan hasil jawaban siswa baik dari hasil pengisian angket maupun soal tes essai.

Kemampuan metakognitif diperoleh berdasarkan hasil pengisian angket oleh siswa. Berdasarkan informasi diperoleh rata-rata persentase kemampuan metakognitif siswa didapatkan dari hasil bagi antara frekuensi kemampuan metakognitif yang diperoleh siswa dan skor maksimum dikali $100 \%$. Kegiatan metakognitif dijelaskan dalam aspek-aspek kemampuan metakognitif yaitu, aspek perencanaan, monitoring dan evaluasi. 
Kemudian Peneliti mengambil tiga kategori dalam kemampuan metakognitif yaitu tinggi, sedang, dan rendah. Distribusi frekuensi kemampuan metakognitif siswa dapat dilihat pada Tabel 1.

\begin{tabular}{|c|c|c|c|}
\hline No & Kategori & Frekuensi & Persentase (\%) \\
\hline 1 & Tinggi & 24 & 43,6 \\
\hline 2 & Sedang & 31 & 56,4 \\
\hline 3 & Rendah & $\begin{array}{c}0 \\
55\end{array}$ & $\begin{array}{c}0 \\
100\end{array}$ \\
\hline
\end{tabular}

Berdasarkan Tabel 1 tentang distribusi kemampuan metakognitif siswa memperlihatkan bahwa tidak ada siswa yang memiliki kemampuan metakognitif dalam kategori rendah. Kategori tinggi yang diperoleh siswa berjumlah 24 siswa dan kategori sedang berjumlah 31 siswa. Kemudian kemampuan metagoknitif siswa menunjukkan bahwa pada pada aspek perencanaan rata-rata persentasenya lebih tinggi dari aspek monitoring dan evaluasi. Secara rinci emampuan metakognitif siswa berdasarkan aspek perencanaan, monitoring dan evaluasi dapat dilihat pada Tabel 2.

Tabel 2. Profil Kemampuan Metakognitif Siswa MAN 1 Singkawang

\begin{tabular}{cc}
\hline Aspek Kemampuan Metakognitif & $\begin{array}{c}\text { Persentase Rata-rata Kemampuan } \\
\text { Metakognitif Siswa }\end{array}$ \\
\hline Perencanaan & $76,59 \%$ \\
Monitoring & $73,09 \%$ \\
Evaluasi & $67,64 \%$ \\
\hline
\end{tabular}

Kemampuan metakognitif siswa juga dianlisis berdasarkan jenis kelamin. Oleh karena itu dilakukan uji $\mathrm{t}$ independen sampel untuk mengetahui apakah terdapat perbedaan kemampuan metakognitif siswa perempuan dan laki-laki. Adapun data kemampuan metakognitif siswa berdasarkan jenis kelamin dapat dilihat pada Tabel 3.

\begin{tabular}{|c|c|c|c|c|c|}
\hline $\begin{array}{l}\text { Kemampuan } \\
\text { Metakognitif }\end{array}$ & $\begin{array}{c}\text { Jenis } \\
\text { Kelamin }\end{array}$ & $\mathbf{N}$ & Mean & $\begin{array}{c}\text { Std. } \\
\text { Deviation }\end{array}$ & $t_{\text {hitung }}$ \\
\hline Perencanaan & $\begin{array}{l}\text { Laki-laki } \\
\text { Perempuan }\end{array}$ & $\begin{array}{l}25 \\
30\end{array}$ & $\begin{array}{l}73,80 \\
78,91\end{array}$ & $\begin{array}{l}8.988 \\
6,620\end{array}$ & 2,428 \\
\hline Monitoring & $\begin{array}{l}\text { Laki-laki } \\
\text { Perempuan }\end{array}$ & $\begin{array}{l}25 \\
30\end{array}$ & $\begin{array}{l}69,10 \\
76,42\end{array}$ & $\begin{array}{l}8,535 \\
9,597\end{array}$ & 2,959 \\
\hline Evaluasi & $\begin{array}{l}\text { Laki-laki } \\
\text { Perempuan }\end{array}$ & $\begin{array}{l}25 \\
30\end{array}$ & $\begin{array}{l}67,30 \\
67,91\end{array}$ & $\begin{array}{l}11,037 \\
11,335\end{array}$ & 0,0203 \\
\hline
\end{tabular}

Taraf signifikan yang digunakan dalam penelitian ini yaitu $5 \%$, berdasarkan hasil uji normalitas yang dilakukan didaptkan bahwa taraf signifikan yang dihasilkan yaitu sebesar 0,200 , yang berarti data tersebut berditribusi normal. Selanjutnya hasil uji homogenitas mendapatkan bahwa taraf signifikan yang dihasilkan yaitu sebesar 0,455 yang berarti data tersebut berditribusi homogen.

Setelah melakukan uji normalitas dan uji homogenitas selanjutnya dilakukan uji $t$ idependen sampel, berbantuan aplikasi SPSS 22. Hasil analisis uji $t$ indenpenden sampel diperoleh nilai t hitung pada aspek kemampuan metakognitif, yang mana thitung untuk setiap aspek kemampuan metakognitif yaitu, perencanaan $t_{\text {hitung }}=2,428$ monitoring thitung $=2,959$ dan evaluasi $t_{\text {hitung }}=0,0203$, sedangkanuntuk $t_{\text {tabel }}=2,005$, hal ini menjukkan bahawa nilai thitung pada aspek 
perencanaan dan monitoring $>t_{\text {tabel }}$ sedangkan nilai thitung pada aspek evaluasi $<$ tabel. Sehingga dapat ditarik kesimpulan terdapat perbedaan kemampuan metakognitif siswa laki-laki dan siswa perempuan pada aspek perencanaan dan aspek monitoring. Sedangkan pada aspek evaluasi tidak terdapat perbedaan kemampuan metakognitif pada setiap aspek antara siswa laki-laki dan siswa perempuan.

Hasil penelitian menunjukan bahwa setiap siswa dengan tingkat kemampuan yang berbeda memiliki kemampuan metakognitif yang berbeda dalam menyelesaikan soal. Siswa di ambil masing-masing satu untuk setiap kategori kemampuan metakognitif yang berbeda. Siswa yang memilik nilai kemampuan metakognitif dalam kategori tinggi dan siswa yang memiliki nilai kemampuan metakognitif dalam kategori sedang. Berdasarkan hasil analisis yang telah dilakukan untuk kemampuan metakognitif siswa pada setiap aspek kemampuan metakognitif didaptkan hasil rata-rata persentase kemampuan metakognitif siswa yaitu untuk aspek perencanaan sebesar 76,59\%, monitoring sebesar 73,09\% dan evaluasi sebesar $67,64 \%$. Berikut uraian hasil analisis setaiap aspek kemampuan metakognitif berdasarkan kategori tinggi dan sedang .

Perencanaan berdasarkan analisis data diketahui bahwa aspek perencanaan memiliki persentase rata-rata paling tinggi, tingginya persentase rata-rata aspek perecanaan ini dikarenakan siswa sudah memiliki pengetahuan metakognitif pada saat menyelesaikan suatu permasalahan dan melakukan aktivitas metakognitif, sehingga siswa dapat memahami langkah-langkah awal yang harus dilakukan dalam meyelesaikan masalah. Pernyataan ini didukung oleh Sholihah (2016) mengungkapkan saat siswa menyelesaikan suatu permasalahan pada tahap perencanaan aktivitas siswa yaitu; 1) pengetahuan awal apa yang bisa mebantuku menyelesaikan tugas ini?, 2) kearah mana pikiranku ini akan membawaku?, 3) apa yang pertama kali harus aku lakukan?, 4) mengapa aku mebaca bagian ini?. Namun pada saat menyelesaikan soal tidak semua siswa menggunakan aktivitas metakognitifnya dengan baik. Sehingga dengan kemampuan metakognitif yang berbeda hasil siswa mengerjakan soal juga berbeda. Siswa dengan kemampuan metakognitif tinggi memahami apa yang diingankan oleh soal dengan baik. Siswa dapat menuliskan yang diketahui dan ditanya dan dapat menentukan persamaan yang akan digunakan serta menggunakan simbol-simbol fisika dengan benar saat menyelesaikan soal. Hal ini sesuai dengan yang dinyatakan oleh Fitrianti et al. (2016) bahwa siswa mengidentifikasi apa saja yang diketahui untuk menentukan tujuan atau hasil dari tugas itu. Sedangkan Siswa dengan kemampuan metakognitif sedang pada saat menyelesaikan soal hanya memenuhi satu indikator yaitu dapat menuliskan yang diketahui dan ditanyakan dalam soal namun siswa belum mampu untuk menentukan persamaan yang akan digunakan dalam menyelesaikan soal atau sebaliknya.

Monitoring merupakan suatu aktivitas memantau secara luas yang membantu orang meyakini tahu tentang kemajuan yang dicapai dalam memahami dah mengingat akan suatu hal. Monitoring juga aktivitas menilai kinerja saat tindakan berlangsung termasuk mencocokkan pada tujuan pribadi maupun tuntutan tugas Realita dilapang pada aspek monitoring siswa dengan kemampuan metakognitif tinggi dalam menyelesaikan soal pada materi listrik statis sudah memenuhi indikator yang ada dalam aspek monitoring. Siswa paham akan konsep yang berkaitan dengan soal pada materi tersebut, karena dengan pemahaman konsep yang baik siswa dapat mengingat dan menerapkan rumus yang digunakan dengan benar. Pernyatan ini didukung oleh hasil penelitian Kholid (2018) yang menyatakan

J urnal Pendidikan Fisika dan Keilmuan (J PFK), Vol. 6, No. 1, Maret 2020, 39-46. 
bahwa pemahaman konsep yang baik akan mempermudah siswa untuk mengingat dan menentukan rumus yang diterapkan. Sementara itu siswa dengan kemampuan metakognitif sedang mampu memenuhui satu indikator yang ada yaitu, siswa mengontrol atau memantau langkah penyelesaian dari informasi yang telah diketahui dalam soal. Sedangkan untuk indikator menerapkan rumus dengan benar siwa belum mampu memenuhinya dengan baik.

Aspek evaluasi berdasarkan analisis data dalam penelitian ini memiliki ratarata persentase paling rendah. Rendahnya persentase rata-rata aspek evaluasi ini desebabkan masih bnyak siswa yang tidak melakukan pemeriksaan apakah hasil telah sesuai dengan tujuan. Dari hasil jawaban siswa terlihat bahwa siswa dengan kemampuan metakognitif tinggi melakukan pemeriksaan kembali terhadap langkah-langkah penyelesaian soal dan mendaptkan hasil jawab yang tepat sesuai dengan harapan, dengan demikian siswa sudah melakukan evaluasi dengan baik Pernyataan ini bertolak belakang dengan penelitian Kholid (2018) bahwa siswa yang memiliki kemampuan tinggi tidak melakukan evaluasi karena siswa sudah meyakini bahwa pekerjaanya sudah benar. Sedangkan tidak melakukan pemeriksaan kembali terhadap langkah-langkah yang telah dilakukan dalam meyelesaikan soal sehingga siswa tidak mendapatkan hasil jawaban yang tepat. Karena penelitian ini ditinjau berdasarkan jenis kelamin maka dipilih 30 orang siswa perempuan dan 25 orang siswa laki-laki. Berdasarkan uji $t$ independen sampel secara keseluruhan yang telah dilakukan untuk melihat apakah terdapat perbedaan anatara kemampuan metakognitif siswa laki-laki dan siswa perempuan, hasil yang diperoleh yaitu terdapat perbedaan antara kemampuan metakognitif siswa laki-laki dan siswa perempuan khusunya pada aspek perencanaan dan aspek monitoring. Dimana nilai thitung $>t_{\text {tabel }}(2,236>2,005)$. Berdasarkan hasil analisis siswa perempuan lebih baik pada aspek perencanaan dan monitoring dikarenakan siswa perempuan sudah melakukan aktivitas metakognitif dengan baik pada tahap awal menyelesaikan soal listrik statis dan sudah melakukan pemeriksaan kembali terhadap langkah-langkah pngerjaan soal. Sedangkan pada tahap evaluasi tidak terdapat perbedaan antara siswa laki-laki dan siswa perempuan sehingga dapat dikatakan setiap siswa memiliki kemampuan metakognitif yang sama dalam menyelesaikan soal yang diberikan pada materi listrik statis. Hal ini sejalan dengan penelitian yang dilakukan oleh (Khairunnisa \& Setyaningsih, 2017) yang mendapatkan kemampuan metakognitif siswa perempuan lebih baik dari kemampuan metakognitif siswa laki-laki, hal tersebut dikarenakan siswa laki-laki belum menggunakan kemampuan metakognitifnya dengan baik. Namun hasil penelitian ini bertolak belakang Turan and Demirel (2010) yang menyatakan bahwa tidak terdapat perbedaan yang signitifkan yang disebabkan oleh jenis kelamin terhadap kemampuan metakognitif siswa.

\section{KESIMPULAN}

Kemampuan metognitif siswa dalam menyelesaikan soal di MAN 1 Singkawang dapat disimpulkan sebagai berikut : (1) Kemampuan metakognitif siswa berdasarkan setiap aspek kemampuan metakognitif berada dalam kategori sedang, dimana aspek perencanaan memiliki rata-rata sebesar 76,59\%, aspek monitoring memiliki rata-rata sebesar $73,09 \%$ dan evaluasi memiliki rata-rata sebesar $67,64 \%$. Terdapat perbedaan kemampuan metakognitif anatara siswa laki-laki dan siswa perempuan dalam menyelesaikan soal-soal listrik statis yang diberikan, hal ini ditunjukan dari hasil uji $\mathrm{t}$ independent sampel mendapatkan ( $\left.t_{\text {hitung }}=2,236>t_{\text {tabel }}=2,005\right)$. 


\section{DAFTAR PUSTAKA}

Aswadi, R., Fadiawati, N., \& Abdurrahman, A. (2018). Meningkatkan Kemampuan Metakognisi Siswa pada Pembelajaran Fisika Menggunakan Lembar Kerja Siswa Berbasis Inkuiri Terbimbing. J urnal Inovasi dan Pembelajaran Fisika, 5(1), 43-54.

Dilla, S. C., Hidayat, W., \& Rohaeti, E. E. (2018). Faktor gender dan resiliensi dalam pencapaian kemampuan berpikir kreatif matematis siswa SMA. J ournal of Medives: J ournal of Mathematics Education IKIP Veteran Semarang, 2(1), 129136.

Djudin, T. (2017). Using metacognitive strategies to improve reading comprehension and solve a word problem. J ournal of Education, Teaching and Learning, 2(1), 124-129.

Fitrianti, F., Rochaminah, S., \& Rizal, M. (2016). Analisis Metakognisi Siswa SMP Negeri I Buko Dalam Memecahkan Masalah Matematika. Mitra Sains, 4(1), 5865.

Iskandar, S. M. (2016). Pendekatan keterampilan metakognitif dalam pembelajaran sains di kelas. Erudio J ournal of E ducational Innovation, 2(2), 13-20.

Juwariyah, S. (2018). Analisis J enis Kesalahan Siswa Dalam Menyelesaikan Soal Fisika Materi Listrik Statis di MAN 6 Jombang Universitas Jember]. Perpustakaan UNEJ. https://repository.unej.ac.id/bitstream/handle/123456789/88406/SITI\%20JUWA RIYAH\%20-\%20140210102095_.pdf?sequence=1\&isAllowed=y

Kemendikbud. (2016). Salinan Lampiran Peraturan Menteri Pendidikan dan Kebudayaan Republik Indonesia Nomor 22 Tahun 2016 Tentang Standar Proses Pendidikan Dasar dan Menengah. Kementerian Pendidikan dan Kebudayaan.

Khairunnisa, R., \& Setyaningsih, N. (2017). Analisis Metakognisi Siswa Dalam Pemecahan Masalah Aritmatika Sosial Ditinjau Dari Perbedaan Gender.

Kholid, M. N. (2018). Deskripsi Metakognisi Siswa Dalam Menyelesaikan Soal Matematika Berbasis Pisa Pada Konten Change And Relationship Siswa SMP Negeri 3 Boyolali Universitas Muhammadiyah Surakarta].

Muhali. (2013). ANALISIS KEMAMPUAN METAKOGNISI SISWA DALAM PEMBELAJARAN KIMIA SMA. J urnal Kependidikan Kimia "Hydrogen", 1(1), 17.

Sholihah, U. (2016). Membangun Metakognisi Siswa dalam Memecahkan Masalah Matematika. Ta'allum: J urnal Pendidikan Islam, 4(1), 83-100.

Sugiyono. (2017). Metode Penelitian Pendidikan Pendekatan Kuantitatif, Kualitatif, dan $R \& D$. Alfabeta.

Turan, S., \& Demirel, Ö. (2010). In what level and how medical students use metacognition? A case from Hacettepe University. Procedia-Social and Behavioral Sciences, 2(2), 948-952. 